\title{
Analisis Ketimpangan Pendidikan pada Masa Covid-19 di Nagari Sisawah Kabupaten Sijunjung
}

\author{
Reindy Rudagi ${ }^{1}$, Felia Siska ${ }^{2 *}$ \\ ${ }^{1,2}$ STKIP PGRI Sumatera Barat, Padang, 25111, Indonesia \\ *email: feliasiska17@gmail.com
}

\begin{abstract}
Abstrak
Indonesia mengalami tekanan akibat bencana Covid-19. Ancaman yang terjadi mengakibatkan terganggunya aktivitas dari segala sektor kehidupan terutama pada sektor pendidikan. Sektor pendidikan diharuskan untuk melakukan pembelajaran secara daring. Fokus penelitian ini adalah menganalisis faktor ketimpangan pendidikan pada masa Covid-19 di Nagari Sisawah Kabupaten Sijunjung dan solusi mengatasi ketimpangan tersebut. Penelitian ini menggunakan pendekatan kualitatif. Metode pengumpulan data dimulai dari observasi partisipan, wawancara mendalam dan dokumentasi. Analisis data diawali dengan pengumpulan data, reduksi data, penjayian data, dan penarikan kesimpulan. Hasil penelitian ini menunjukkan faktor-faktor yang menyebabkan terjadinya ketimpangan adalah: 1) Kondisi wilayah Nagari Sisawah yang terletak dipedalaman. 2) Nagari Sisawah merupakan salah satu daerah yang tidak terjangkau jaringan seluler dan jaringan internet, sehingga menyulitkan siswa untuk belajar daring. 3) Tidak semua anak memiliki peralatan atau media penunjang sekolah atau kuliah daring. 4) Sulitnya menentukan metode pembelajaran untuk anak-anak yang bersekolah di dalam Nagari Sisawah. Dari temuan tersebut, solusi untuk mengatasi ketimpangan yaitu melakukan kerjasama dengan berbagai pihak terutama pihak pemerintah, sekolah dan orangtua untuk peningkatan kualitas pendidikan. Disamping itu, melakukan kolaborasi yang tidak hanya pada level lokal melainkan level global.
\end{abstract}

Kata Kunci: Covid-19, ketimpangan pendidikan, wilayah pedesaan

\begin{abstract}
Indonesia is under pressure due to the Covid-19 disaster. Threats that occur result in disruption of activities from all sectors of life, especially in the education sector. The education sector is required to conduct online learning. The focus of this research is to analyze the factors of educational inequality during the Covid-19 period in Nagari Sisawah, Sijunjung Regency and solutions to overcome this inequality. This study uses a qualitative approach. The data collection method started from participant observation, in-depth interviews and documentation. Data analysis begins with data collection, data reduction, data presentation, and drawing conclusions. The results of this study indicate that the factors that cause inequality are: 1) The condition of the Nagari Sisawah area which is located in the interior. 2) Nagari Sisawah is one area that is not covered by
\end{abstract}


cellular networks and internet networks, making it difficult for students to study online. 3) Not all children have equipment or media to support school or online lectures. 4) It is difficult to determine the learning method for children who attend school in Nagari Sisawah. From these findings, the solution to overcome inequality is to collaborate with various parties, especially the government, schools and parents to improve the quality of education. In addition, to collaborate not only at the local level but at the global level.

\section{Keywords: Covid-19, education inequality, rural areas}

\section{Pendahuluan}

Kebijakan "belajar dari rumah" sebagai respons dari kehadiran pandemik Covid19 memiliki dampak serius kepada 68 juta siswa dan 3,2 juta guru. Pembelajaran jarak jauh (PJJ) beresiko menghambat bahkan menghentikan proses pembelajaran bagi sekolah-sekolah di wilayah terpencil karena keterbatasan akses internet dan biaya yang harus dikeluarkan setiap murid. Sekolah dan murid-murid yang tidak memiliki fasilitas memadai mengalami kesulitan melanjutkan proses belajar-mengajar (Dzaljad, 2020; Fitri et al., 2020; Zahrawati \& Nurhayati, 2021). Hal tersebut berpotensi meningkatkan disparitas atau ketimpangan pendidikan di Indonesia. Dalam upaya mengendalikan penyebaran pandemik Covid-19, pada pertengahan Maret 2020, pemerintah memutuskan untuk menghentikan sementara kegiatan belajar di sekolah (Herliandry et al., 2020). Sekolah dianggap sebagai salah satu media yang berpotensi memperluas penyebaran Covid-19 karena adanya interaksi secara langsung antara murid, guru, dan orang tua dalam jarak yang dekat (Adriani et al., 2021).

Menurut Santoso, ada dua masalah besar akibat pembelajaran jarak jauh, yakni: Pertama, keterbatasan akses terhadap internet yang stabil. Banyak wilayah di Indonesia belum dijangkau oleh internet, bahkan sinyal komunikasi dan listrik pun belum mencapai beberapa wilayah 3T (tertinggal, terdepan, dan terluar).Salah satu building block dari sebuah pembelajaran jarak jauh yang efektif adalah kecepatan internet yang memadai dan stabil (Adriani et al., 2021; Zahrawati \& Ramadani, 2021). Tanpa koneksi yang stabil, murid tidak mungkin mendapatkan materi pembelajaran secara utuh dan proses pemahaman pun terbatas dan dibatasi oleh internet. Ketimpangan akses terhadap internet tersebut dapat terlihat jelas ketika kita membandingkan data antara wilayah perkotaan dan pedesaan. Kedua, permasalahan kapabilitas tenaga pengajar yang kesulitan beradaptasi dengan metode pembelajaran PJJ. Secara umum PJJ menambahkan beban kepada guru karena kebanyakan dari mereka baru pertama kali melakukan pembelajaran dari jarak jauh. Dengan adanya pandemik Covid-19, sekolah mengerti bahwa proses belajar tidak bisa dilakukan dalam waktu yang lama seperti pada situasi normal. Akibatnya, guru terpaksa memadatkan materi pembelajaran yang banyak dalam beberapa jam saja.

Gambaran pembelajaran daring juga dikaji dari pemerataan jaringan internet di seluruh wilayah di Indonesia. Berdasarkan data Asosiasi Penyelenggara Jasa Internet Indonesia (APJI1) Februari 2020 bahwa jumlah pengguna internet di Indonesia sebanyak 143,26 Juta atau sekitar $55 \%$. Artinya masih ada $45 \%$ yang belum tersentuh internet. Bagi sekolah dan guru yang berada di wilayah terpencil, permasalahannya juga tentang cara mengatasi keterbatasan-keterbatasan fundamental seperti akses internet yang tidak ada atau tidak stabil, keterbatasan finansial keluarga murid, dan fasilitas 
digital sekolah yang terbatas. Bagi wilayah pedesaan yang masih bisa mengakses internet, biaya menjadi kendala karena keluarga murid yang tidak bisa membayar pulsa dan paket data internet bagi anaknya.Pada akhirnya guru kerap terpaksa mendatangi murid ke rumah masing-masing meskipun beresiko menyebarkan penyakit Covid-19.

Berbicara ketimpangan pendidikan, kita kaji dulu dari istilah pendidikan.Tujuan dari pendidikan nasional tidak saja hanya mencetak sumber daya manusia yang cerdas akan tetapi juga mampu mencetak kepribadian yang berkarakter, berakhlak, kreatif, memiliki misi visi dan bertanggung jawab serta sebagai warga negara yang baik. Kesuksesan seseorang tidak pernah lepas dari potensi yang dimiliki oleh orang tersebut. Potensi dalam arti tidak saja berbicara tentang skill akan tetapi meliputi kemampuan seseorang mengimplementasikan potensi yang dimiliki untuk orang banyak, kemampuan mengelola diri dan orang lain (Arsyad, 2010; Todaro \& Smith, 2011). Pendidikan merupakan salah satu faktor penting dalam pembangunan ekonomi. Hal ini dilandasi pernyataan beberapa ekonomi bahwa sumber daya manusia yang berkualitas merupakan faktor penting dalam pembangunan ekonomi. Adapun untuk meningkatkan kualitas sumber daya manusia adalah dengan melalui pendidikan. Oleh karena itu, untuk memajukan suatu daerah yang perlu ditingkatkan adalah pendidikannya (Santoso, 2020).

Kemudian pendapat yang berbeda tentang ketimpangan pendidikan merupakan suatu kondisi yang menggambarkan pemerataan pendidikan yang diterima oleh masyarakat. Ketimpangan pendidikan menjadi sangat penting dalam mengetahui efektivitas dari sistem pendidikan dan sebagai alat ukur untuk mengevaluasi proses pendidikan. Ketimpangan pendidikan dapat diakibatkan oleh berbagai macam faktor yang terkait dengan akses terhadap jenjang pendidikan (Suratman et al., 2014).

Menurut Tesfeye dalam Evi (2020) terdapat 4 faktor yang mempengaruhi ketimpangan pendidikan yakni: 1) Karakteristik keluarga yang terdiri dari pendapatan, tingkat kesejahteraan, ukuran keluarga, tingkat pendidikan orang tua. 2) Karakteristik anak atau siswa yang terdiri dari tingkat kemampuan siswa, kesehatan, gizi, daya kognitif, dan jenis kelamin. 3) Kualitas pendidikan di antaranya kualitas pengajaran, rasio siswa dan guru, ukuran kelas, kualifikasi guru, kualitas ruang kelas dan peralatan belajar, kurikulum, infrastruktur sekolah dan pemeliharaan rutin, pasokan listrik,fasilitas air minum dan toilet. 4) Tingkat rate of return dari pendidikan. Negara dengan tingkat ketimpangan pendidikan tinggi secara konsisten menunjukkan tingkat inovasi yang lebih rendah, rendahnya tingkat efisiensi produksi, dan kecenderungan untuk mentransmisi kemiskinan lintas.

Sedangkan menurut Efendy (2016) ada tiga jenis kesenjangan dalam pendidikan tarsebut yakni: 1) Kesenjangan struktural yang disebabkan karena kebijakan. 2) Kesenjangan kultural karena budaya, misalnya ada orang yang masih menganggap pendidikan kurang penting. 3) Kesenjangan spasial karena perbedaan desa dan kota. Yang tinggal di desa harus ada usaha lebih banyak untuk dapat mengakses.

Sumatera Barat merupakan salah satu provinsi yang mengalami permasalahan belum merata jaringan internet ke suluruh nagari di kabupaten Kota. Berikut Kabupaten/Kota yang bermasalah dalam akses jaringan internet. 
Tabel 1. Data Kabupaten Kota di Provinsi Sumatera Barat yang Belum Ada Jaringan Internet

\begin{tabular}{clc}
\hline No & Kabupaten/Kota & Jumlah Nagari/Daerah \\
\hline 1 & Agam & 4 \\
2 & Mentawai & 2 \\
3 & Pasaman Barat & 4 \\
4 & Sijunjung & 19 \\
5 & Lima Puluh Kota & 9 \\
6 & Solok Selatan & 6
\end{tabular}

Sumber: Antara News, (Elfis, 2020)

Berdasarkan Tabel 1, gambaran yang bisa diperoleh bahwa wilayah yang belum terjangkau internet itu berada di kabupaten-kabupaten dan salah satu wilayah yang banyak titik-titik belum terjangkau internet adalah kabupaten Sijunjung yakni sebanyak 19 titik. Sehingga potensi ketimpangan pendidikan di Kabupaten Sijunjung berpotensi sangat besar. Salah satu daerah di Kabupaten Sijunjung yang belum menikmati akses internet adalah Nagari Sisawah Kecamatan Sumpur Kudus yang merupakan salah satu desa atau istilah di Sumatera Barat dikenal dengan "Nagari" yang terletak diperbatasan Provinsi Sumatera Barat dan Provinsi Riau (DetikNews, 2020). Keterbatasan jaringan internet yang menjadi masalah utama anak yang ada di Nagari Sisawah untuk belajar Jarak jauh pada masa pandemi Covid-19. Di Nagari ini terdapat 7 PAUD, 7 TK, Sekolah SD, dan 2 SMP. Berdasarkan latar belakang yang dipaparkan di atas, maka penelitian ini bertujuan untuk menganalisis ketimpangan pendidikan Nagari Sisawah Kabupaten Sijunjung pada Masa Covid-19. Adapun yang menjadi rumusan masalah dalam penelitian ini adalah 1) Apa saja faktor penyebab ketimpangan pendidikan di Nagari Sisawah pada masa Covid-19? 2) Bagaimana solusi dalam mengatasi ketimpangan pendidikan di Nagari Sisawah pada masa Covid-19? Selanjutnya, temuan penelitian ini memberikan konstribusi kepada pemerintah daerah dalam pengambilan kebijakan bagi peserta didik yang melaksankan pendidikan secara daring dengan membangun infrastruktr jaringan internet. Bagi pihak sekolah untuk bisa melonggarkan kurikulum kepada peserta didik dalam proses pembelajaran.

\section{Metode Penelitian}

Penelitian ini menggunakan pendekatan kualitatif (Bungin, 2001). Penelitian ini dilakukan di Nagari Sisawah atau Desa Sisawah, Kecamatan Sumpur Kudus, Kabupaten Sijunjung, Provinsi Sumatera Barat. Metode pengumpuan data yaitu observasi partisipan, wawancara mendalam dan pengumpulan data dokumen. Unit analisis individu dan kelompok dalam melihat fenomena pendidikan pada wilayah Nagari Sisawah pada masa Covid-19. Unit analisis penelitian ini adalah masyarakat. Analisis data mengunakan model Miles \& Huberman (2014) yang dimulai dengan pengumpulan data, reduksi data, penyajian data dan penarikan kesimpulan. Informan penelitian ini masyarakat yang tinggal di wilayah Sisawah dan peserta didik yang masih duduk 
dibangku pendidikan baik tingkat sekolah dasar, sekolah menegah pertama, sekolah menegah atas dan perguruan tinggi.

\section{Pembahasan}

\section{Gambaran Umum Nagari Sisawah}

Nagari Sisawah atau Desa Sisawah merupakan salah satu Nagari yang ada di Kecamatan Sumpur Kudus Kabupaten Sijunjung, Provinsi Sumatera Barat. Nagari ini sebelah Barat berbatasan dengan Kecamatan Sijunjung, sebelah timur berbatasan dengan Kecamatan Koto VII, sebelah Utara berbatasan dengan Kecamatan Sijunjung, sebelah selatan berbatasan dengan Provinsi Riau (Rimbo/HutanLisun).

Penduduk Nagari Sisawah tersebar di 7 buah jorong yaitu Jorong Koto Baru, Jorong Koto Sisawah, Jorong Simawik, Jorong Rumbai, Jorong Sungai Tampang, Jorong Subalin dan Jorong Kabun. Jarak antara Jorong dengan Jorong yang lainnya cukup relatif jauh, lebih kurang $7 \mathrm{~km}$ dari ibukota nagari. Kantor walinagari terletak di tengah-tengah kenagarian Sisawah, jarak tempuh ke jorong-jorong membutuhkan waktu yang hampir sama. Jorong Simawik yang letaknya $7 \mathrm{~km}$ dari pusat pemerintahan nagari. Wilayahnya terdiri dari perbukitan yang dipenuhi oleh perkebunan karet sebagai mata pencarian utama penduduk. Pemukiman penduduk sebagian besar dilembah dan sepanjang aliran sungai batang Sumpur. Keadaan ekonomi penduduk Jorong Simawik dapat disimpulkan masih tergolong menengah kebawah, kondisi transportasi yang belum memadai dan pemanfaatan sumber daya alam belum maksimal. Keadaan topografi dan kondisi penduduk yang hampir sama dengan Jorong Simawik yakninya Jorong Rumbai.

Jorong berikutnya, yakni Jorong Sungai Tampang yang terletak disebelah barat nagari Sisawah, jorong ini adalah satu-satunya jalan keluar dari nagari Sisawah yang menggunakan roda empat. Dilihat dari keadaan alamnya, wilayah ini dikelilingi gunung batu, tidak ada sungai besar. Pemukiman penduduk di lembah-lembah gunung, letaknya $7 \mathrm{~km}$ dari pusat pemerintahan nagari. Jorong ini terdapat banyak sekali "ngalau" yang tanahnya digunakan untuk pupuk pertanian sawah di nagari Sisawah. Dengan kondisi topografi wilayahnya, pemukiman penduduk tidak merata karena dipenuhi oleh gunung batu.

Mengarah ke selatan, terdapat pemukiman sekelompok penduduk disepanjang aliran batang Sumpur yang hampir mencapai muara di Batang Sinamar, wilayah ini disebut dengan nama Subalin merupakan salah satu jorong di nagari Sisawah yang berbatasan dengan Nagari Padang Laweh kecamatan Koto VII, Subalin juga sebagai pintu masuk menuju Nagari Sisawah dengan jalan alternative dari pusat kabupaten dan provinsi, kondisi jalan aspal semen hanya dilalui roda dua menelusuri tepi sungai batang sumpur. Jorong ini dikelilingi oleh gunung batu yang tidak aktif yang dibawahnya dilalui aliran batang Sumpur.

Jorong Koto Baru dan Jorong Koto Sisawah terletak di pusat pemerintahan Nagari, kantor wali nagari pasar nagari Sisawah berada di dalam wilayah Jorong Koto Baru. Untuk Jorong kabun, hampir sama topografinya dengan jorong Subalin, samasama dikelilingi oleh gunung batu yang tidak aktif, tetapi jorong kabun lebih terjal dan penuh bebatuan di sekitar pemukiman penduduk. 


\section{Faktor-faktor Penyebab Terjadinya Ketimpangan Pendidikan di Nagari Sisawah pada Masa Covid-19}

Kesenjangan pendidikan yang terdapat di pedesaan, terdapat berbagai aspek dan faktor penyebabnya. Diperparah dengan adanya kuliah jarak jauh dengan media atau platform tatap maya atau belajar bersifat online. Sehingga kondisi ini menjadi permasalahan besar bagi masyarakat pedesaan, terutama di Nagari Sisawah. Suatu hal kondisi yang tidak pernah dibayangkan oleh masyarakat untuk tidak bersekolah di dalam ruang kelas. Harus belajar dari rumah. Adapun ketimpangan pendidikan yang terjadi di Nagari Sisawah pada masa Covid-19 meliputi kondisi wilayah di pedalaman, daerah yang tidak terjangkau oleh jaringan telepon seluler dan jaringan internet, tidak semua anak memiliki peralatan penunjang untuk kuliah daring, dan sulitnya menentukan metode pembelajaran untuk anak-anak yang bersekolah di dalam Nagari Sisawah.

\section{1) Kondisi wilayah di pedalaman}

Berdasarkan gambaran umum wilayah Nagari Sisawah dapat diketahui bahwa Nagari ini terletak di Wilayah Pedalaman Kabupaten Sijunjung. Kondisi Wilayah yang masih alami, terletak di tepi Rimbo Lisun atau Rimba yang membatasi wilayah Sumatera Barat dengan Provinsi Riau. Kondisi ini juga mempengaruhi tingkat pendidikan di Nagari Sisawah.

Akses transportasi merupakan salah satu faktor penentuan perkembangan suatu wilayah pada suatu daerah. Berikut gambaran jalan sebagai akses di Nagari Sisawah ke Pusat Kecamatan Sumpur Kudus Kabupaten Sijunjung.

Gambar 1. Kondisi akses jalan di Nagari ke pusat lecamatan

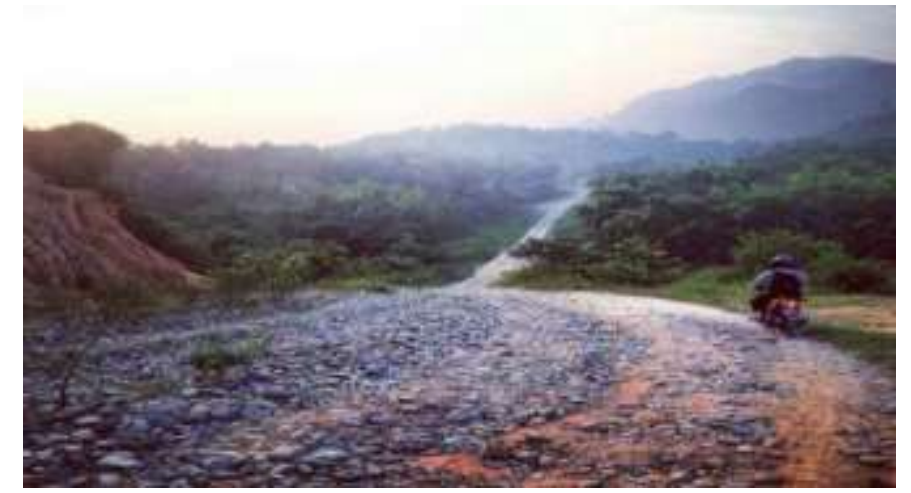

Jalan yang ada pada Gambar 1 merupakan jalan yang dilalui oleh anak-anak di Nagari Sisawah menuju lokasi yang memiliki jaringan internet. Berdasarkan hasil wawancara penulis dengan salah seorang mahasiswa di Perguruan Tinggi di Kota Padang yang berasal dari Nagari Sisawah yang harus mencari jaringan ke sebuah bukit, ditengah hutan bersama teman-temannya. 
"Jam 06.30 wib sudah harus berangkat menuju puncak sinyal (istilah daerah yang ada sinyal), karena jauh dijalan. Kalau terlambat, maka ketinggalan untuk kuliah online. Jaringan internet lambat kalau datang siang".

Kondisi transportasi dan akses terbatas sehingga menjadi hambatan bagi anakanak untuk kuliah online. Kondisi ini jauh dari idealnya potret pendidikan Indonesia. Selain akses jalan, kondisi penerangan juga menjadi faktor penting untuk kuliah online karena kuliah menggunakan teknologi berupa handphone dan laptop. Bantuan penerangan atau PLN untuk jorong Simawik, Jorong Rumbai, Jorong Subalin baru dialiri listrik tahun 2019. Artinya Nagari ini memang benar- benar berada di pedalaman.

\section{2) Daerah yang tidak terjangkau oleh jaringan telepon seluler dan jaringan internet}

Permasalahan besar lain yang dihadapi oleh anak-anak sekolah di Nagari Sisawah adalah tidak ada jaringan internet dan sinyal telepon seluler, memang permasalahan utama pada daerah pedalaman dalam belajar jarak jauh adalah tidak terjangkau jaringan internet. Bagi sekolah dan guru yang berada di wilayah terpencil, permasalahannya juga tentang cara mengatasi keterbatasan-keterbatasan fundamental seperti akses internet yang tidak ada atau tidak stabil, keterbatasan finansial keluarga murid, dan fasilitas digital sekolah yang terbatas. Penulis melihat ini merupakan kondisi yang mempengaruhi seluruh aspek, baik dari sisi siswa yang belajar maupun guru yang memberi materi pembelajaran. Pada satu sisi, kebijakan pemerintah untuk tidak memperbolehkan ke sekolah untuk belajar, pada sisi lain guru dan siswa di Nagari Sisawah tidak punya media lain untuk melanjutkan proses pembelajaran. Sehingga ini menjadi dilema dan permasalahan bagai guru dan anak-anak yang sekolah.

Keseluruhan jorong (dusun) di Nagari Sisawah tidak memiliki akses internet dan sinyal telepon. Sehingga permasalahan ini merata di daerah ini. Setiap Jorong ada sekolah PAUD, TK dan SD. Sedangkan untuk Sekolah Menengah Pertama hanya ada di pusat Nagari yakni di Jorong Koto Sisawah dan Jorong Kabun. Untuk anak-anak yang belajar di luar Nagari Sisawah seperti siswa Sekolah Menengah Atas dan Perguruan Tinggi, tentu harus mencari wilayah tertentu yang ada jaringan internet.

Untuk Lokasi jaringan internet harus ditempuh lebih kurang 1/2-1 jam dan bukan terletak pada wilayah pemukiman. Seperti yang terlihat pada Gambar 2. 
Gambar 2. Kondisi anak-anak Nagari Sisawah belajar daring
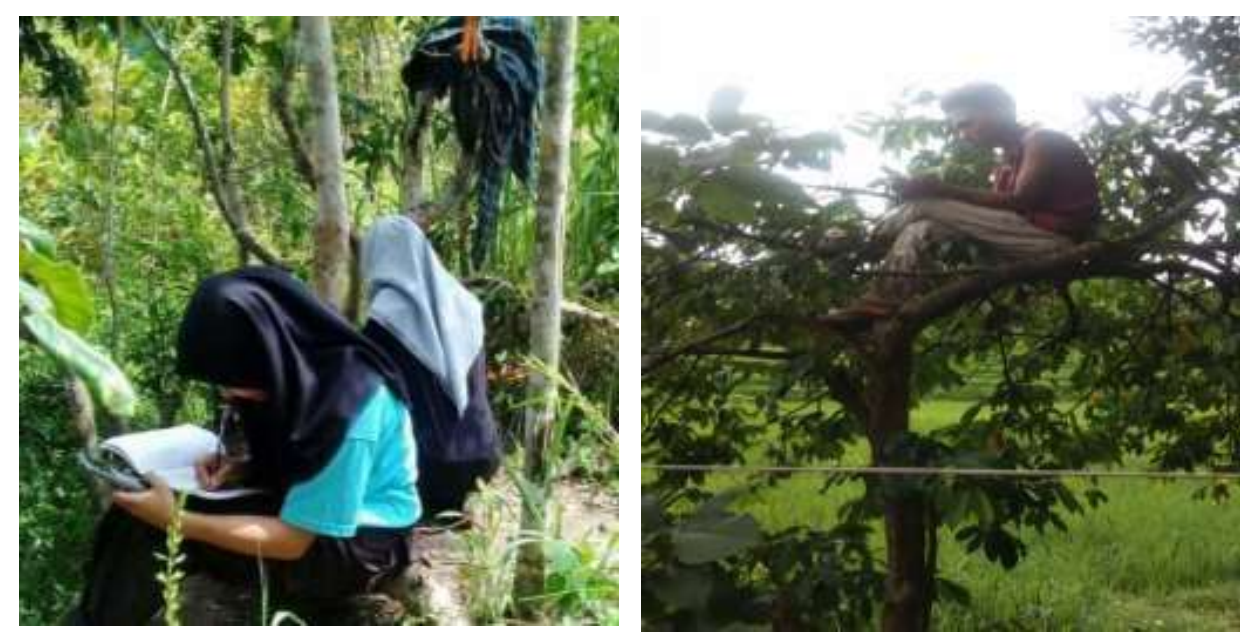

\section{3) Tidak semua anak memiliki peralatan penunjang untuk kuliah daring}

Permasalahan lain pada pembelajaran daring ini adalah ketersediaan peralatan atau sarana dan prasarana yang dimiliki oleh anak yang terbatas. Permasalahan ini lebih banyak melanda anak-anak yang bersekolah di luar karena mereka harus belajar daring atau online. Seperti wawancara penulis dengan orangtua salah satu siswa yang bersekolah di SMA Negeri di Muaro Sijunjung.

"Ado-ado sae sekolah kini, harus pakai HP bagai. Dela (anaknya) dak nawuh HP deh. Ambo dak ado pitih mambolinyo. Kecek ambo ka dela, dak sikolah lai. Tapi dek alah satangah $j$, sayang kalau bonti.Tapaso holing pitih ka induk samang, beko dibayiah sangenek- ngengek wak manimbang gota. Mudahan pitih PKH kaluao, jadi itu nankadibayiahkan”.

(Ada-ada saja sekolah zaman sekarang, harus pakai hanphone sehala.Dela (anaknya) tidak punya Hanphone yang bisa digunakan belajar daring.Saya tidak punya uang untuk membelinya.Kata Saya berhenti saya sekolah, tapi karena sudah dipertengahan, sayang berhenti.Maka, terpaksa saya pinjam uang kepada Induk Semang.Nanti rencana dicicil pada waktu menimbang karet.Tapi mudah- mudahan Uang PKH cair, nanti bisa dibayarkan tanpa harus dicicil).

\section{4) Sulitnya menentukan metode pembelajaran untuk anak-anak yang bersekolah di dalam Nagari Sisawah}

Sejak keluarnya Surat Edaran Kemendikbud Nomor 40 Tahun 2020 tentang "Pelaksanaan Kebijakan Pendidikan dalam Masa Darurat Penyebaran Corona Virus Disease (COVID-19)", Menteri Pendidikan dan Kebudayaan (Mendikbud), Nadiem Makarim, mengambil sejumlah kebijakan untuk menghadapi pandemi. Kebijakan tersebut di antaranya adalah penghapusan Ujian Nasional; perubahan sistem Ujian Sekolah; perubahan regulasi Penerimaan Peserta Didik Baru (PPDB); dan penetapan belajar dari rumah (pembelajaran daring).

Kemudian kebijakan ini diturunkan ke level bahwa yakni dinas Pendidikan tingkat Kabupaten bahwa persekolah dengan tatap muka di dalam kelas dalam jumlah 
yang banyak ditiadakan. Belajar dari rumah, menggunakan platform pembelajaran online. Permasalahan ini menjadi dilema yang harus dicari solusinya bersama.

Guru-guru yang mengajar di Nagari Sisawah pada umumnya hampir $85 \%$ berasal dari pusat kabupaten Sijunjung. Artinya tidak berdomisili di Nagari Sisawah. Berdasarkan wawancara dengan salah satu Guru SD di Jorong Simawik diperoleh informasi bahwa disepakati pada siswa di tingkat PAUD dan Taman Kanak-kanak diliburkan, untuk Anak Sekolah Dasar (SD) masuk 2 kali seminggu untuk mengumpulkan tugas dan mengambil tugas berikutnya. Untuk anak Sekolah Menengah Pertama, berganti sekolah dua seminggu dan Gurunya mengadakan piket untuk menerima dan memberikan tugas kepada siswa.

\section{Solusi Mengatasi Ketimpangan Pendidikan di Nagari Sisawah}

Untuk menyelesaikan permasalahan ketimpangan pendidikan di Nagari Sisawah pada masa Covid-19, sudah ada kebijakan-kebijakan yang dilakukan oleh berdasarkan faktor-faktor penyebab ketimpangan dan diskusi peneliti dengan masyarakat di Nagari Sisawah, maka direkomendasikan solusinya sebagai berikut:

\section{1) Pemerintah}

Sebagai masyarakat yang tinggal di wilayah Indonesia, tentunya sudah mengetahui bahwa masyarakat Indonesia itu memiliki keanekaragaman dari karakteristiknya wilayahnya. Ada yang dipedalaman dan perkotaan. Keanekaragaman itu ternyata bisa juga menjadi faktor yang menimbulkan ketimpangan pendidikan. Oleh karena itu, sangat penting adanya sebuah usaha untuk meningkatkan sarana dan prasarana penunjang pendidikan, meningkatkan kualitas sumber daya manusia yang ada. Peningkatan kualitas penduduk dapat dilakukan melalui berbagai usaha. Upayaupaya tersebut adalah: a) Memperbaiki kualitas pendidikan. b) Meningkatkan fasilitas kesehatan, baik kualitas tenaga medis maupun peningkatan pelayanan kesehatan. c) Melakukan pemberdayaan kelompok masyarakat, misalnya dengan memberikan penyuluhan atau pengarahan pada masyarakat.

Kondisi ketertinggalan di Nagari Sisawah menjadi permasalahan yang harus dituntaskan atau dilakukan percepatan pembangunan. Nagari ini berpotensi wisata alam yang besar karena terkenal dengan Negeri Seribu Ngalau. Harus ada akses jalan yang bagus sehingga siswa mudah melewati jalan tersebut menuju tempat sinyal pada masamasa daring sekarang.

Dinas Pendidikan memberikan aturan yang berbeda untuk daerah yang tidak ada sinyal karena kondisi yang berbeda. Jadi tidak bisa disamakan aturannya. Daerah-daerah ini sebetulnya tidak urgent untuk belajar di rumah karena mereka berinteraksi sebatas penduduk yang ada di nagari tersebut, dan minim peluang untuk terkonfirmasi wabah Covid-19.

Kesulitan sinyal seharusnya bisa dicarikan solusinya oleh pemerintah Nagari dengan memperbolehkan anak-anak belajar di Kantor Wali Nagari karena kantor Walinagari disediakan jaringan khusus, tanpa memungut bayaran karena untuk sekolah online saja sudah memberatkan orangtua dan anak-anak. Selanjutnya, harus ada pemasangan tower penangkap sinyal dalam waktu dekat di Nagari Sisawah, sehingga permasalahan jaringan bisa diatasi karena masalah jaringan. Masalah ini adalah masalah yang urgen pada era digital danteknologi. 


\section{2) Sekolah}

Sekolah memberikan pelayanan pendidikan darurat pada kondisi darurat Covid-19 ini, sehingga dipastikan siswa bisa menerima ilmu walaupun sekolah tidak penuh. Tugas yang diberikan alangkah bagusnya direview atau di evaluasi, sehingga proses pembelajaran tetap jalan walaupun kondisi yang belum memungkinkan.

\section{3) Masyarakat/orang tua}

Permasalahan lain yang timbul dari belajar dari rumah atau tidak belajar malahan adalah kontrol penggunaan handphone atau media sosial. Anak-anak yang pergi ke tempat sinyal, dari pagi sampai sore, tidak ada pengawasan dari orang tua. Apa saja yang diakses oleh siswa selain dari materi pelajaran karena siswa di Nagari Sisawah tidak merata sebelumnya yang punya handphone android. Artinya anak-anak ini baru memakai alat elektronik ini.Jadi perlu sosialisasi cerdas menggunakan handphone dan orang tua mengawasi anak-anak menggunakan handphone. Orang tua harusnya juga belajar bagaimana mengoperasikan handphone bagi yang belum bisa, karena perlu mengecek handphone anak-anak, agar tidak terjerumus pada hal-hal yang diperlu ditonton, dibaca atau di download oleh anak-anak.

\section{Kesimpulan}

Penelitian ini menemukan bahwa faktor-faktor yang menyebabkan terjadinya ketimpangan pendidikan di Nagari Sisawah selama masa Covid-19 adalah: 1) Kondisi wilayah Nagari Sisawah yang terletak dipedalaman. 2) Nagari Sisawah merupakan salah satu daerah yang tidak terjangkau jaringan seluler dan jaringan internet, sehingga menyulitkan siswa untuk belajar daring. 3) Tidak semua anak memiliki peralatan atau media penunjang sekolah atau kuliah daring. 4) Sulitnya menentukan metode pembelajaran untuk anak-anak yang bersekolah di dalam Nagari Sisawah. Dari temuan tersebut, solusi untuk mengatasi ketimpangan yaitu melakukan kerjasama dengan berbagai pihak terutama pihak pemerintah, sekolah dan orangtua untuk peningkatan kualitas pendidikan. Berkaitan dengan hal tersebut, keterbatasan penelitian ini adalah belum mampu menggambarkan secara komprehensif keadaan pelaksanaan pendidikan di Nagari Sisawah, sehingga saran untuk peneliti selanjutnya dapat menggunakan berbagai tekhnik pengumpulan data untuk menyempurnakan hal tesebut. Selain itu, untuk mengatasi permasalahan ketimpangan pelaksanaan pembelajaran di masa Covid19, perlu dikembangkan dalam kajian media pembelajaran, strategi pembelajaran dan metode pembelajaran daring di wilayah pedesaan.

\section{Referensi}

Adriani, S. R. C., Khoirot, S., Sawitri, S. S., \& Nurjanah, N. (2021). Dampak Pembelajaran Jarak Jauh Pada Masa Covid-19 di SMK Muhammadiyah 1 Sukoharjo. JURNAL PENDIDIKAN, 30(1), 53-58.

Ari Budi Santoso. (2020). Potret Pendidikan di Tahun Pandemi: Dampak COVID-19 Terhadap Disparitas Pendidikan di Indonesia. CSIS CommentariesDMRU-079-ID, $1(1)$.

Bungin, B. (2001). Metodologi penelitian kualitatif. Jakarta: Rajawali Press.

DetikNews. (2020). Warga Nagari Sisawah Keluhkan Jalan Terisolir-Susah Sinyal ke 
Andre Rosiade. News.Detik.Com.

Dzaljad, R. G. (2020). Transformasi Sosial dalam Proses Pendidikan di Masa Pandemi Covid-19. MAARIF, 15(2), 305-324.

Elfis, M. (2020). Sumbar data "titik buta" internet untuk dukung belajar daring. Padang.

Fitri, W., Octaria, M., \& Suwanny, N. (2020). Tantangan dan Solusi terhadap Ketimpangan Akses Pendidikan dan Layanan Kesehatan yang Memadai di Tengah Pandemi Covid-19. Jurnal Syntax Transformation, 1(10), 766-776.

Herliandry, L. D., Nurhasanah, N., Suban, M. E., \& Kuswanto, H. (2020). Pembelajaran pada masa pandemi covid-19. JTP-Jurnal Teknologi Pendidikan, 22(1), 65-70.

L.Arsyad. (2010). Ekonomi Pembangunan (Edisi ke-5). Yogyakarta: Unit Percetakan STIM YKPN Yogyakarta.

M. Todaro \& S.C. Smith. (2011). Pembangunan Ekonomi: Edisi kesebelas Jilid 1. (Edisi 11). Jakarta: Erlangga.

Miles, M. B., \& Huberman, A. M. (2014). Qualitative data analysis: a methods sourcebook. USA: Sage Publications.

Nugrahani, F., \& Hum, M. (2014). Metode penelitian kualitatif. Solo: Cakra Books.

Suratman, B., Soesatyo, Y., \& Soejoto, A. (2014). Analisis Faktor Yang Memengaruhi Ketimpangan Pendidikan. Jurnal Ilmu Pendidikan, 20(2).

Zahrawati, F., \& Nurhayati. (2021). The challenge of online learning in curriculum2013 during COVID-19 pandemic: study of social science teachers at MAN 2 Parepare. Sociological Education, 2(1), 9-14.

Zahrawati, F., \& Ramadani, A. N. (2021). Problematika implementasi kurikulum 2013 terhadap proses pembelajaran pada masa pandemik COVID-19. Bidayatuna: Jurnal Pendidikan Guru Madrasah Ibtidaiyah, 04(01), 59-74. 